\title{
New Walnut Cultivars: Maras 18, Sutyemez 1, and Kaman 1
}

Mehmet Sutyemez ${ }^{1}$

\author{
Department of Horticulture, Faculty of Agriculture, University \\ Kahramanmaras Sutcu Imam, Kahramanmaras, Turkey
}

Additional index words. English walnut, Juglans regia, walnut breeding

Walnuts are one of several fruit species indigenous to Turkey, which has a long history of fruit cultivation (Şen, 1986). Turkey has 11 million walnut trees with an annual production of $210,000 \mathrm{t}$, and is ranked fourth among the walnut-producing countries of the world (Sütyemez, 2015). Three new walnut cultivars with superior fruit yield and quality were developed through positive mass selection using

Table 1. Tree and phenological characteristics of walnut cultivars.

\begin{tabular}{|c|c|c|c|c|}
\hline Characteristics & Maras 18 & Sutyemez 1 & Kaman 1 & Chandler $^{z}$ \\
\hline Date of budbreak & 4-8 Apr. & 2-6 Apr. & 6-10 Apr. & 13-16 Apr. \\
\hline Harvest date & 9-12 Sept. & 11-14 Sept. & 18-20 Sept. & $3-10$ Oct. \\
\hline Defoliation date & 1-4 Nov. & 3-5 Nov. & 5-9 Nov. & 3-10 Dec. \\
\hline Seedling vigor & High & High & High & Intermediate \\
\hline Tree vigor & High & High & High & High \\
\hline Growth habit & Semierect & Semierect & Spreading & Semierect \\
\hline Branching & Intermediate & Dense & Dense & Dense \\
\hline Leaflet shape & Broad elliptic & Broad elliptic & Broad elliptic & Broad elliptic \\
\hline Leaf color & Green & Green & Green & Green \\
\hline Rachis color & Yellow & Yellow & Yellow & Yellow \\
\hline Shoot pubescence & Glabrous & Glabrous & Glabrous & Glabrous \\
\hline Shoot color & Green & Green & Green & Green \\
\hline Leaf and rachis pubescence & Glabrous & Glabrous & Glabrous & Glabrous \\
\hline Leaf and/or rachis persistence & Intermediate & Intermediate & Intermediate & Intermediate \\
\hline Dichogamy & Protandry & Protogyny & Protogyny & Protandry \\
\hline $\begin{array}{l}\text { Duration of female bloom } \\
\text { overlapped by the staminate } \\
\text { bloom (\%) }\end{array}$ & 10 & 20 & 10 & 10 \\
\hline Catkin abundance & Intermediate & Heavy & Heavy & Heavy \\
\hline Lateral bud flowering (\%) & $75-80$ & $70-75$ & $75-80$ & $85-90$ \\
\hline Female flower abundance & Intermediate & Intermediate & Heavy & Heavy \\
\hline Stigma color & Yellow & Yellow & Yellow & Yellow \\
\hline Hull persistence after nut fall & Slight & Slight & Slight & Slight \\
\hline Hull dehiscence & Dehiscent & Dehiscent & Dehiscent & Dehiscent \\
\hline Estimated yield & Intermediate & Intermediate & High & High \\
\hline
\end{tabular}

${ }^{2}$ Reference cultivar: Chandler.

selected genotypes from the Kahramanmaras and Kaman regions of Turkey.

\section{Origin}

In the first phase of the breeding program, 170 genotypes were selected among 200,000 genotypes grown from seed in the Kahramanmaras and Kaman regions. In the second phase, an orchard was created using the 170 genotypes and grafting studies were conducted. Of the genotypes studied in the second phase, 25 were determined as promising. Through further selection, three genotypes were selected and patented. The other promising genotypes are still under study. This study was carried out between 1994 and 2010 (Sütyemez, 1998). The Walnut Breeding Program of Kahramanmaras Sutcu Imam University released the three new cultivars as Maras 18, Sutyemez 1, and Kaman 1 in 2009 and 2010.

\section{Method}

Phenological and pomological evaluations were carried out according to the International Plant Genetic Resources Institute criteria during each step of the breeding program. (Anonymous, 1994; Hendricks et al., 1985; UPOV, 1999).

\section{Description}

Maras 18. This cultivar is characterized by a high yield after 8 years of growth and by an early harvest date $\approx 3$ weeks before 'Chandler' (Table 1). The cultivar is resistant to codling moth (Cydia pomonella). Leafing occurs 2 weeks before 'Chandler'. Male and female flowers are borne mostly on lateral shoots. Lateral buds are $75 \%$ fruitful. 'Maras 18' is protandrous with a large percentage of male and female overlap (Table 1; Fig. 1). Potential pollinizers include 'Bilecik', 'Chandler', and

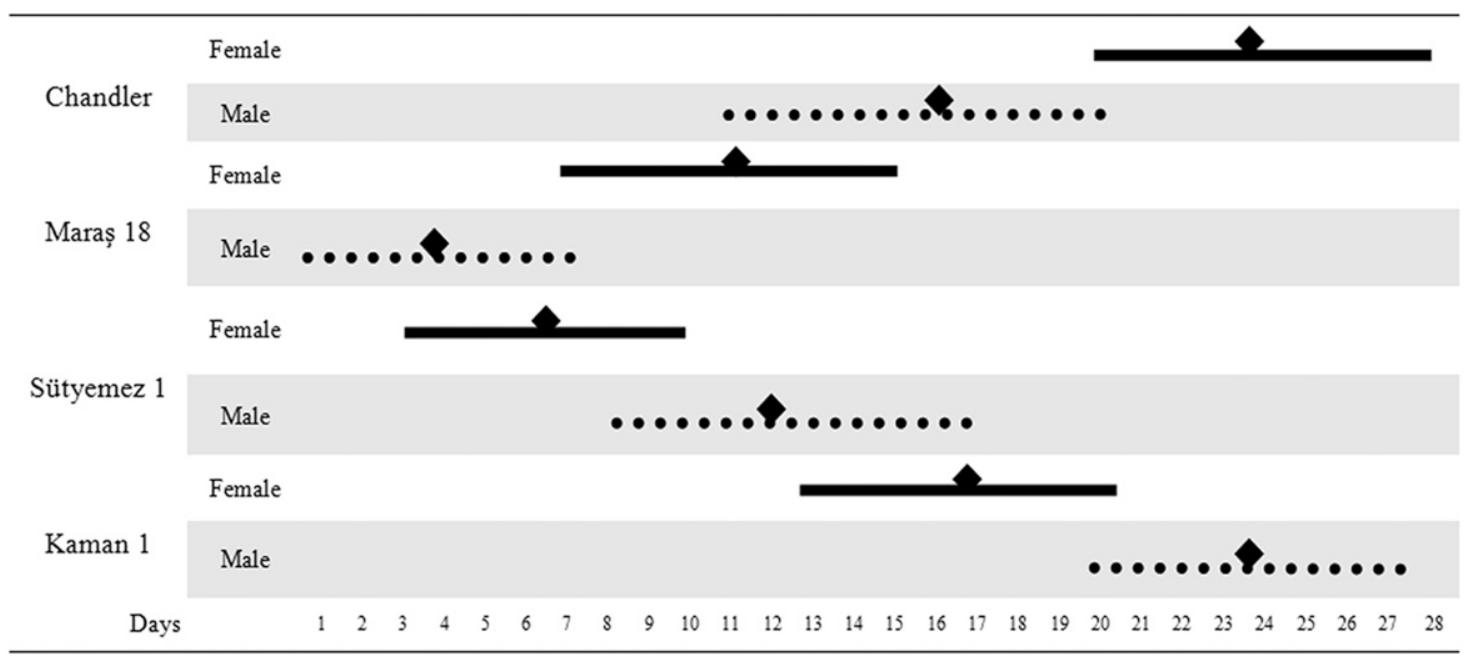

Fig. 1. Relationship of pollen-shedding period to time of peak pistillate bloom. 
'Sutyemez 1'. Nuts are light colored, smooth, large, and round with good seal strength. Dehydrated nut weight is around 13-15 g. Kernels of 'Maras 18' are light colored, easy to remove from the shell, and at 7-9 $\mathrm{g}$, make up $53 \%$ to $57 \%$ of the whole fruit (Table 2). Nuts are harvested around the 2nd week of September in Kahramanmaras region. The kernel is easily removed from the shell as a whole or as two halves,resulting in a very high ratio of intact kernels (Table 2), which is considered as an important quality characteristic of a walnut cultivar (Fig. 2). The kernel is edible even before full maturation, which is preferred by some consumers and classified as "fresh walnut." According to consumer opinions, 'Maras 18' has a more pleasant aroma and taste compared with 'Chandler'.

Sutyemez 1. This cultivar bears flowers mostly on laterals (70\%) and fruit yield is high. Leafing out occurs $20 \mathrm{~d}$ earlier than 'Chandler' and harvest date is $23 \mathrm{~d}$ earlier than 'Chandler' (Table 1). The cultivar is moderately resistant to the codling moth and walnut blight disease. 'Sutyemez 1' is protogynous (Fig. 1) and suggested pollinizer is 'Sebin'. The cultivar has high quality and very large nut size averaging 25-27 g (Fig. 2). Kernels make up $\approx 49 \%$ to $51 \%$ of the total nut weight and are extra light colored with a smooth surface (Table 2). Sensory analyses have given high scores to 'Sutyemez 1'. Consumers appreciate the cultivar also because it has a smooth and very large nutshell (Fig. 2).

Kaman 1. The cultivar was produced by selective breeding (Sütyemez, 1998) in the region of Kirsehir, Kaman, Turkey. The cultivar has a high kernel percentage, and bears flowers mostly laterally $(80 \%)$. The cultivar leafs out $10 \mathrm{~d}$ before 'Chandler' and fruits are harvested $15 \mathrm{~d}$ before 'Chandler' (Table 1). The cultivar has a small ratio of a leaf blight scores. 'Kaman 1' is protogynous (Fig. 1) and suggested potential pollinizers are 'Franquette', 'Bilecik', 'Pedro', and 'Şen 2'. The nut shape of the cultivar is very unique and can be easily distinguished from the other cultivars (Fig. 2). Nuts of this cultivar weigh around 13-14 g, and have a medium-rough surface. The kernel is light colored, weighs around $7-8 \mathrm{~g}$, and makes up $\approx 52 \%$ to $57 \%$ of the total nut weight (Table 2). Sensory analyses have given high scores to 'Kaman 1' as well.

\section{Availability}

The cultivars are recommended for all walnut-growing regions in Turkey except for where early spring frost risk is high.

Grafts, budwoods, and saplings of cultivars Maras 18, Sutyemez 1, and Kaman 1 are

Received for publication 25 May 2016. Accepted for publication 10 Aug. 2016.

${ }^{1}$ Corresponding author. E-mail: sutyemez@ksu. edu.tr.
Table 2. Nut characteristics of walnut cultivars.

\begin{tabular}{|c|c|c|c|c|}
\hline Characteristics & Maras 18 & Sutyemez 1 & Kaman 1 & Chandler $^{z}$ \\
\hline Nut shape & Ovate & Long trapezoid & Other & Ovate \\
\hline Nut diameter (mm) & 35.10 & 42.39 & 31.38 & 33.28 \\
\hline Nut length (mm) & 41.50 & 51.04 & 36.90 & 35.47 \\
\hline Shell texture & Smooth & Smooth & Medium & Rough \\
\hline Shell color & Very light & Very light & Medium & Medium \\
\hline Shell seal & Intermediate & Intermediate & Intermediate & Intermediate \\
\hline Shell strength & Intermediate & Intermediate & Intermediate & Intermediate \\
\hline Shell integrity & $\begin{array}{l}\text { Complete } \\
\text { shell }\end{array}$ & $\begin{array}{l}\text { Complete } \\
\text { shell }\end{array}$ & $\begin{array}{l}\text { Complete } \\
\text { shell }\end{array}$ & $\begin{array}{l}\text { Complete } \\
\text { shell }\end{array}$ \\
\hline Shell thickness & 1.36 & 1.52 & 1.48 & 1.42 \\
\hline Packing tissue thickness & Medium & Medium & Medium & Medium \\
\hline $\begin{array}{l}\text { Nut: shape in longitudinal } \\
\text { section through suture }\end{array}$ & Broad ovate & $\begin{array}{l}\text { Broad } \\
\text { trapezium }\end{array}$ & Broad ovate & Ovate \\
\hline $\begin{array}{l}\text { Nut: shape in longitudinal } \\
\text { section perpendicular } \\
\text { to suture }\end{array}$ & Broad ovate & $\begin{array}{l}\text { Broad } \\
\text { trapezium }\end{array}$ & $\begin{array}{l}\text { Broad } \\
\text { trapezium }\end{array}$ & $\begin{array}{l}\text { Broad } \\
\quad \text { trapezium }\end{array}$ \\
\hline Nut: shape in cross section & Circular & Elliptic & Circular & Circular \\
\hline $\begin{array}{l}\text { Nut: shape of base } \\
\text { perpendicular to suture }\end{array}$ & Rounded & Truncate & Truncate & Truncate \\
\hline $\begin{array}{l}\text { Nut: shape of apex } \\
\text { perpendicular to suture }\end{array}$ & Pointed & Emarginate & Truncate & Emarginate \\
\hline Nut: prominence of apical tip & Strong & Medium & Medium & Weak \\
\hline $\begin{array}{l}\text { Nut: depth of grove along } \\
\text { pad on suture }\end{array}$ & Medium & Shallow & Medium & Medium \\
\hline $\begin{array}{l}\text { Nut: structure of surface } \\
\text { of shell }\end{array}$ & Slightly grooved & $\begin{array}{l}\text { Slightly } \\
\text { grooved }\end{array}$ & $\begin{array}{l}\text { Slightly } \\
\text { grooved }\end{array}$ & $\begin{array}{l}\text { Slightly } \\
\text { grooved }\end{array}$ \\
\hline $\begin{array}{l}\text { Nut: thickness of primary and } \\
\text { secondary membranes }\end{array}$ & Thin/thin & Thin/thin & Thin/medium & Thin/thin \\
\hline $\begin{array}{l}\text { Nut: adherence of } \\
\text { two halves of shell }\end{array}$ & Medium & Medium & Medium & Weak \\
\hline In-shell nut weight (g) & $13-15$ & $25-27$ & $13-14$ & $12-14$ \\
\hline Kernel weight (g) & $7-9$ & $12-14$ & $7-8$ & $6-7$ \\
\hline Kernel percentage (\%) & $53-57$ & $49-51$ & $52-57$ & $48-51$ \\
\hline Kernel veins $(\%)$ & Smooth & Smooth & Intermediate & Smooth \\
\hline Kernel flavor & Very satisfactory & Satisfactory & Satisfactory & Satisfactory \\
\hline Kernel fill & Well & Well & Well & Well \\
\hline Kernel plumpness & Plump & Plump & Plump & Plump \\
\hline Ease of removal of & Very easy & Very easy & Very easy & Very easy \\
\hline
\end{tabular}

kernel halves

Kernel shrivel (\%)

Kernel color

${ }^{2}$ Reference cultivar: Chandler.

\begin{tabular}{|c|c|c|c|}
\hline J joht & int & iobt & 0 \\
\hline
\end{tabular}
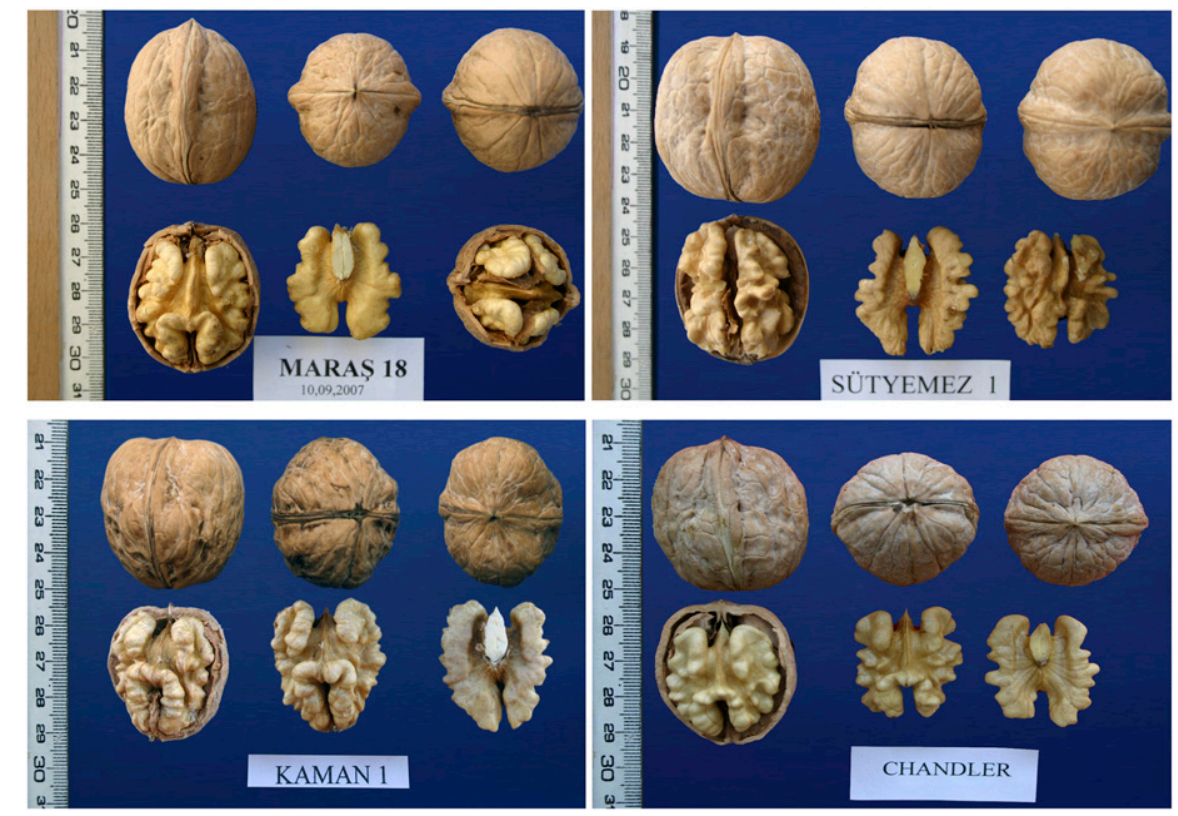

Fig. 2. Fruits of 'Maras 18', 'Sutyemez 1', 'Kaman 1', and 'Chandler' walnut cultivars. 
available through the Foundation Seed and Plant Materials Service of Kahramanmaras Sutcu Imam University, Kahramanmaras, Turkey.

\section{Literature Cited}

Anonymous. 1994. Descriptors for walnut (Juglans Spp). International Plant Genetic Resources Institute, Rome, Italy
Hendricks, L.C., G.H. McGranahan, D.E. Ramos, B. Iwakiri, and H. Forde. 1985. Selection of varieties, p. 46-51. In: D.E. Ramos (ed.). Walnut orchard management. Div. Agr. Natl. Res. Univ. of Calif. Publ. 21410.

Şen, S.M. 1986. Ceviz yetiştiriciliği. Eser Matbaası, Samsun, Turkey, $229 \mathrm{~s}$.

Sütyemez, M. 1998. Kahramanmaraş bölgesinde ceviz seleksiyonu ve seçilmiş bazı tiplerin döllenme biyolojileri üzerine araştırmalar.
Ç.Ü. Fen Bilimleri Enstitüsü Doktora Tezi 401, Adana, Turkey.

Sütyemez, M. 2015. Sert kabuklu meyveler ders notları. KSU Ziraat Fakültesi, Kahramanmaraş, Turkey.

UPOV. 1999. Union internationale pour le protection des obtentions vegetales draft guidelines for the conduct of tests for distinctness, uniformity and stability walnut (Juglans regia $\mathrm{L}$.), TG/ 125/6. Geneva, Switzerland. 